\title{
Performance of FRC Produced with Mineral Admixtures and Waste Plastic Fibers Under Sulfate Attack
}

\author{
Sadat Ali Khan, Zaheer Ahmed, Afiya A
}

\begin{abstract}
Fiber reinforce concrete has been in use for more than 30 years now. It is a kind of high strength concrete used in construction industry particularly for structures carrying tensile loads. Use of fiber reinforced concrete imparts higher tensile, flexural strength, shear strength and crack resistance property to the structure. Also it is seen that FRC can be used in the construction in sulfate environment as the steel fibers help in resisting deterioration of concrete due to sulfate ions. But production of FRC is quite expensive. Currently construction industry is focusing more on low cost construction by different ways like by replacing cement by some of the mineral admixtures that are actually waste products and hence if properly used in concrete can reduce the cost of concrete. Replacing steel fibers with waste plastic fibers will also reduce the cost provided that the replacement percentage is low. Here in this work an effort is made to develop FRC by replacing a part of cement by mineral admixtures Viz., Ground granulated blast furnace slag, Silica fume, Metakaolin and steel fibers by Waste plastic fibers. And the samples thus produced will be subjected to sulfate attack by immersing them in sulfate solution for a period of 90days and these samples were then tested for their strength Viz., Compression, tensile, Flexure and shear. It was seen that we can effectively replace cement by $20 \%$ and that too replacing cement with GGBS is more beneficial as it does not reduce strength as much as it can be seen with other mineral admixtures. Also we can replace steel fibers by $50 \%$ by waste plastic fibers.

Key words - Flexure, Shear, Admixture, GGBS
\end{abstract}

\section{INTRODUCTION}

Concrete is one the most important part in the construction. There is no other material which can replace concrete in terms its compressive strength as well as the ease with which it can be prepared and casted in to any shapes. Concrete is at its best when subjected to compressive forces. And it possesses a considerable strength in Flexure and shear. However concrete cannot solely resist shear and tensile forces. It requires to be reinforced with steel bars. Fiber reinforced concrete is one of the advanced type of concrete where it is produced with addition of fibers to the conventional concrete. Addition of fibers to the concrete helps enhance the strength properties of concrete. Concrete is strong in carrying compressive loads but fails easily when it is subjected to tensile or flexural forces. It has already been seen that addition of steel fibers helps increase shear strength, flexural strength considerably. Steel fibers are quite expensive but they are the best option to arrest the

Revised Manuscript Received on April 12, 2019.

Sadat Ali Khan Lecturer, Dept.of Engineering, Faculty of Engineering, Science and Technology, Maldives National University, Maldives, (khanalisadat@gmail.com)

Zaheer Ahmed, $\mathrm{PhD}$ Scholor International Islamic University Kulalampur, Malaysia. (zahe04@gmail.com)

Afiya A, Assitant Professor Beary's Enviro Architecture Design School, Mangalore (afiya21790@gmail.com) crack propagation in concrete. However, we can use hybrid fibers up to a particular ratio to reduce the cost. Instead of using fully steel fibers we can use any other type of fiber along with steel fibers. This will help reduce the quantity of steel fibers but it should be checked that the steel fiber quantity is not too less.

Cost of the concrete can be considerably controlled if we could reduce the quantity of cement required. In other words, a part of cement should be replaced with something else which would develop similar cementitious property when combined with cement. These are called mineral admixtures. We can find lot of mineral admixtures easily as most these are waste/by products from industries. Examples of mineral admixtures are Fly ash, bottom ash, Ground granulated blast furnace slag, Metakaolin, rice husk ash etc., Fly ash, also known as pulverized fuel ash is obtained from coal industries. It is produced during the burning of powdered coal. It consists of particulates that fly out with flue gases from coal-fired boilers. And bottom ash is the ash that falls at the bottom of the boiler. Depending upon the source from where the coal is obtained and also its composition, the components of fly ash and bottom vary considerably. There are plenty of applications of these ashes but major being its use in concrete as a partial replacement to cement. It is pozzolanic in nature which makes it possible to replace cement up to $30 \%$ by volume.

Ground granulated blast furnace slag is obtained from blast furnace by quenching molten iron slag in water or steam. It is basically glassy and granulated but later ground in to fine powder. Its chemical composition varies depending upon the raw materials used for the production of iron. It is pozzolanic in nature and can be used as a partial replacement to cement in concrete.

Rice husk ash is obtained from rice milling industries. As these industries produce lot of rice husk during processing of rice, this rice husk is used as a fuel in the boilers and when burnt, it turns in to pozzolanic ash that can be used in concrete like other mineral admixtures as explained above.

There have already been lot of experiments done on replacing cement partially by these mineral admixtures and it is seen that a replacement of $25-30 \%$ has been efficient. In this work, an effort has been made to assess the effect of sulfate on the Fiber reinforced concrete produced by replacing a part of cement of mineral admixtures and a part of steel fibers by waste plastic fibers 


\section{PERFORMANCE OF FRC PRODUCED WITH MINERAL ADMIXTURES AND WASTE PLASTIC FIBERS UNDER SULFATE ATTACK}

Sulfate is seen as a deteriorating agent when it comes in contact with concrete. Sulfate can be present in sea water, sewer water, ground water, mixing water and even in some soils. It is seen that the sulfate ions when come in contact. cement surface in any of the above way will affect the strength of concrete by deteriorating it.

Fiber reinforced concrete has been found to perform considerably better compared to conventional concrete in sulfate environment. And hence in this work it is observed that the replacement of steel fibers by waste plastic fiber is not so high that it affects its sulfate resisting characteristics.

\section{Objectives: -}

Following are the objectives of this work.

i. To develop Fiber reinforced concrete by replacing cement partially with mineral admixtures which reduce the disposal problem of mineral admixtures and reduce the cost of FRC as well.

ii. To develop Fiber reinforced concrete by replacing steel fibers partially by waste plastic fibers which helps with reduce plastic waste and reduce the cost of FRC as well.

iii. To find out the optimum quantity of mineral admixtures and waste plastic fibers to be used in FRC that does not affect the strength properties of FRC.

iv. To check the sulfate resistance property of FRC by modifying its ingredient ratio.

v. To check compression, tensile, flexure and shear strength of FRC so developed.

\section{Materials and Methodology:}

FRC is basically produced using ordinary Portland cement, sand, coarse aggregates and steel fibers. In this work ordinary Portland cement was partially replaced by mineral admixtures like Silica fume, Metakaoline, ground granulated blast furnace slag, and steel fibres were partially replaced by waste plastic fibres, high density poly ethylene fibres and the concrete samples thus produced were immersed in a solution of magnesium sulfate for a period of 90days to check the sulfate resistance of FRC.

Properties of materials

\begin{tabular}{|c|c|}
\multicolumn{2}{c}{ Ordinary Portland cement } \\
\hline Specific surface & $3250 \mathrm{~cm}^{2} / \mathrm{gm}$ \\
\hline Normal consistency & $34 \%$ \\
& 3.15 \\
\hline Specific gravity & $35 \mathrm{~min}$ \\
& $320 \mathrm{~min}$ \\
\hline Setting time & \\
a)Initial \\
b) Final & $41.4 \mathrm{~N} / \mathrm{mm}^{2}$ \\
\hline
\end{tabular}

Silica fume

\begin{tabular}{|c|c|}
\hline Specific gravity & 2.28 \\
\hline Specific surface & $15000-20000 \mathrm{~cm}^{2} / \mathrm{gm}$ \\
\hline Bulk density & $1350-1510 \mathrm{~kg} / \mathrm{m}^{3}$ \\
\hline
\end{tabular}

Fig.1 Silica fume

Metakaolin

\begin{tabular}{|c|c|}
\hline Specific gravity & 2.48 \\
\hline Average particle size & $1.5 \mu \mathrm{m}$ \\
\hline Bulk density & $1550-1680 \mathrm{~kg} / \mathrm{m}^{3}$ \\
\hline
\end{tabular}

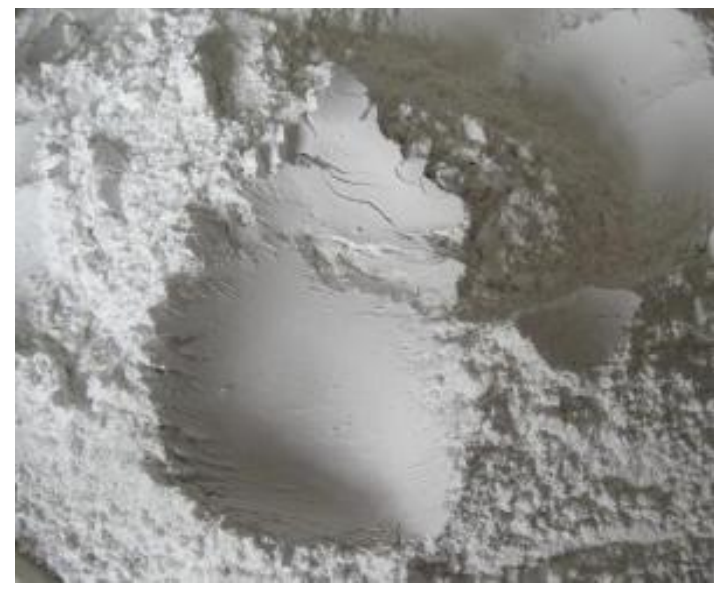

Fig.2 Metakaolin

GGBS

\begin{tabular}{|c|c|}
\hline Specific gravity & 2.85 \\
\hline Specific surface & $450-475 \mathrm{~m}^{2} / \mathrm{kg}$ \\
\hline Bulk density & $1250 \mathrm{~kg} / \mathrm{m}^{3}$ \\
\hline
\end{tabular}

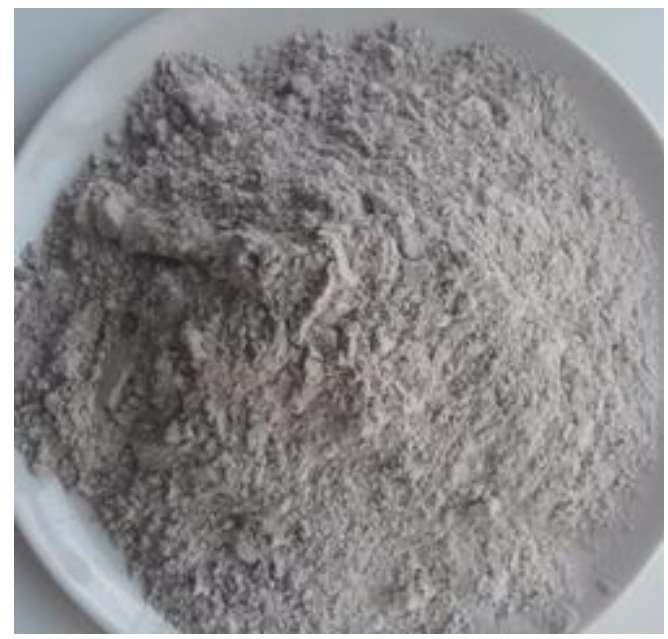

Fig.3 GGBS 
Fine aggregates

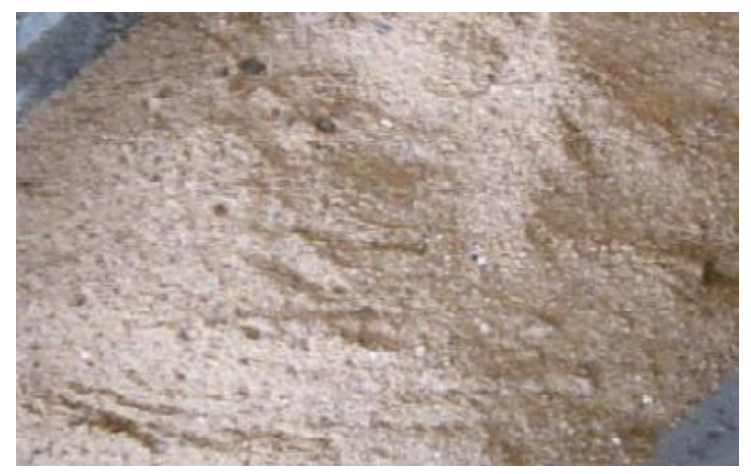

Fig.4 Sand

Coarse aggregates

\begin{tabular}{|c|c|}
\hline Specific gravity & 2.65 \\
\hline Water absorption & $2.0 \%$ \\
\hline Bulk density & $1750 \mathrm{~kg} / \mathrm{m}^{3}$ \\
\hline
\end{tabular}

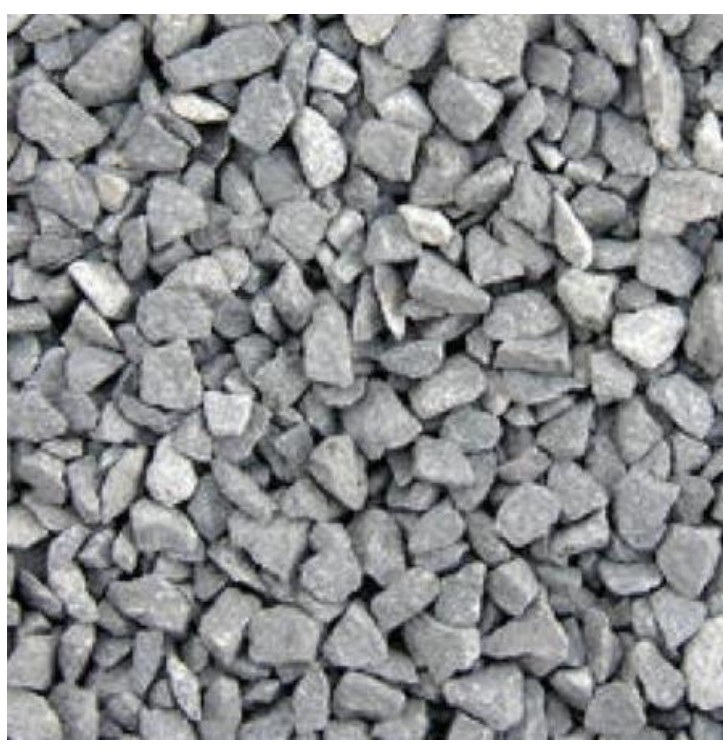

\section{Steel fibers}

Steel fibers of length $35 \mathrm{~mm}$ and width $1 \mathrm{~mm}$ having aspect ratio 35 are used.

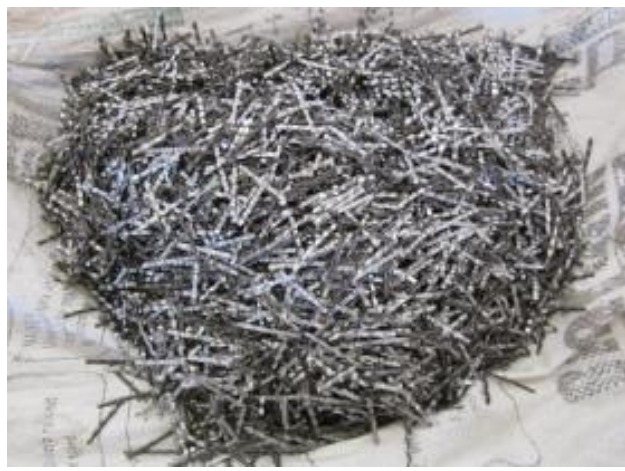

Fig.5 Steel fibers

\begin{tabular}{|c|c|}
\hline Specific gravity & 2.58 \\
\hline Water absorption & $2.5 \%$ \\
\hline Bulk density & $1650 \mathrm{~kg} / \mathrm{m}^{3}$ \\
\hline
\end{tabular}

$H D P E$

High density polyethylene fibres are procured from cutting HDPE oil cans. Fibres are cut to a length of $35 \mathrm{~mm}$, $1 \mathrm{~mm}$ thick and width of $3 \mathrm{~mm}$ obtaining as aspect ratio of 35. Density of HDPE fibre was found to be $900 \mathrm{~kg} / \mathrm{m}^{3}$.

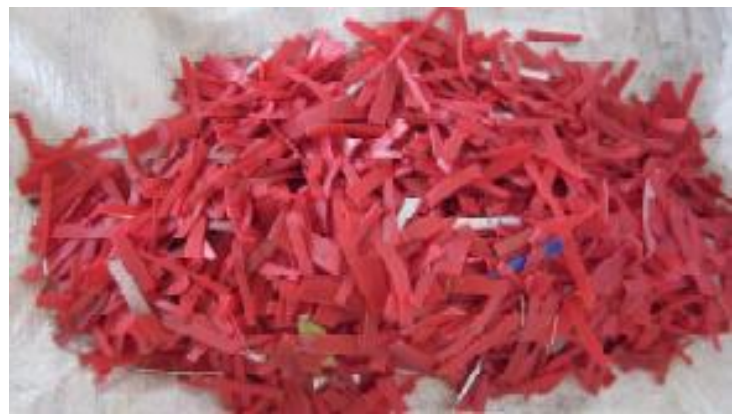

Fig.6 High density polyethylene fibers

Other plastic fibers

Other plastic fibers are obtained by cutting the waste plastic materials like buckets, Jugs, tubs etc. The size of the fibers used here is

$35 \mathrm{~mm}$ length and $1 \mathrm{~mm}$ wide. The density of these fibers varies in the range of $230-300 \mathrm{~kg} / \mathrm{m} 3$ and Aspect ratio of waste plastic fibers is 35 .

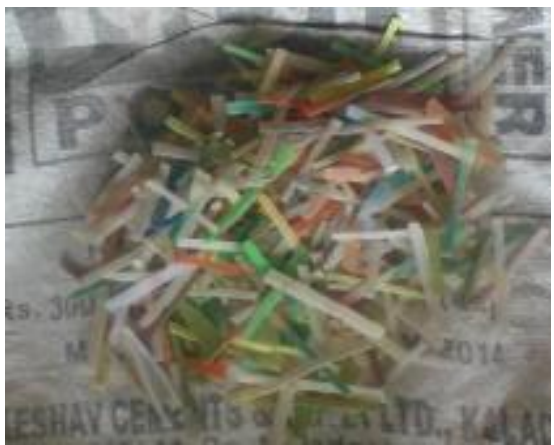

Fig 7 Other plastic fibers

\section{Preparation of FRC}

This work was focused on M25 grade concrete with percentage of total fibers keeping at $2 \%$. The following table gives the details of different FRC samples produced with replacement of cement by mineral admixtures and steel fibers by waste plastic fibers in different ratios

\begin{tabular}{|c|c|c|}
\hline $\begin{array}{c}\text { Combinat } \\
\text { ions }\end{array}$ & $\begin{array}{c}\text { Cement }+ \\
\text { Mineral } \\
\text { admixture }\end{array}$ & $\begin{array}{c}\text { Steel + HDPE + } \\
\text { WP Fibers }\end{array}$ \\
\hline Set 1 & $\begin{array}{c}90 \% \text { cement }+ \\
10 \% \text { silica fume }\end{array}$ & $1 \%+0.5 \%+0.5 \%$ \\
\hline Set 2 & $\begin{array}{c}90 \% \text { cement }+ \\
10 \% \text { Metakaolin }\end{array}$ & $1 \%+0.5 \%+0.5 \%$ \\
\hline Set 3 & $\begin{array}{c}90 \% \text { cement }+ \\
10 \% \text { GGBS }\end{array}$ & $1 \%+0.5 \%+0.5 \%$ \\
& \multicolumn{2}{|c}{} \\
\hline
\end{tabular}

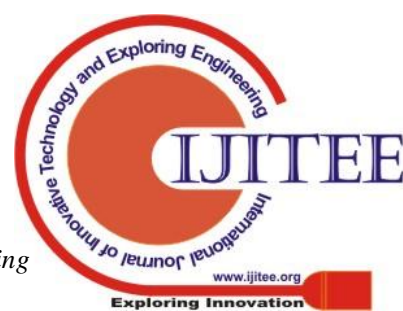




\begin{tabular}{|c|c|c|}
\hline Set 4 & $\begin{array}{c}80 \% \text { cement }+ \\
20 \% \text { silica fume }\end{array}$ & $1 \%+0.5 \%+0.5 \%$ \\
\hline Set 5 & $\begin{array}{c}80 \% \text { cement }+ \\
20 \% \text { Metakaolin }\end{array}$ & $1 \%+0.5 \%+0.5 \%$ \\
\hline Set 6 & $\begin{array}{c}80 \% \text { cement }+ \\
20 \% \text { GGBS }\end{array}$ & $1 \%+0.5 \%+0.5 \%$ \\
\hline Set 7 & $\begin{array}{c}75 \% \text { cement }+ \\
25 \% \text { silica fume }\end{array}$ & $1 \%+0.5 \%+0.5 \%$ \\
\hline Set 8 & $\begin{array}{c}75 \% \text { cement }+ \\
25 \% \text { Metakaolin }\end{array}$ & $1 \%+0.5 \%+0.5 \%$ \\
\hline Set 9 & $\begin{array}{c}75 \% \text { cement }+ \\
25 \% \text { GGBS }\end{array}$ & $1 \%+0.5 \%+0.5 \%$ \\
\hline Set 10 & $\begin{array}{c}100 \%+0+0 \\
\text { Control mix })\end{array}$ & $2 \%+0+0$ \\
\hline
\end{tabular}

Each set includes six samples. After 24 hours of casting the samples were demoulded and cured for 28days. After 28days of curing three Samples of each set were immersed in sulfate solution prepared by mixing magnesium sulfate in water at 5\% concentration for a period of 90days and other three samples were retained as a reference to compare the effect of sulfate on the samples immersed in sulfate solution.

\section{ANALAYSIS RSESULTS \& DISCUSSIONS:-}

\section{Compression test} $150 \times 150 \times 150 \mathrm{~mm}$. The test sample is placed centrally on the compression testing machine and load is applied continuously and uniformly on the surface parallel to the direction of tamping. The load is increased until the specimen fails and the maximum load carried by each specimen during the test was recorded as shown in fig 8

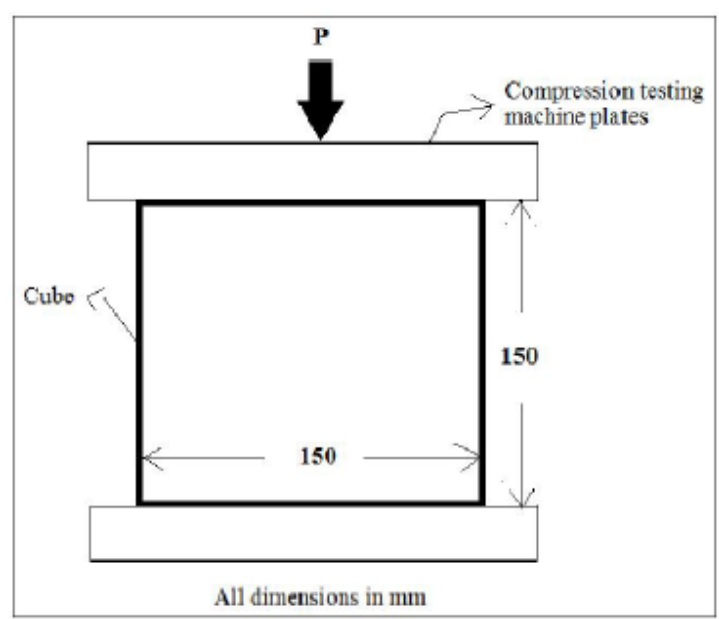

Fig 8 Compression testing

Compressive strength was calculated as follows

Compressive strength $=P / A$

\section{Tensile test}

Standard Size of the tensile test sample is $150 \mathrm{~mm}$ diameter and $300 \mathrm{~mm}$ height. Diametrical lines were drawn on two ends of the specimen so that they are in the same axial plane. A plywood strip was placed on the center of the lower platen. The specimen was placed on the plywood strip
Standard size of the Compression test specimen is

and aligned such that the lines marked on the end of the specimen are vertical and centered over the plywood strip. The second plywood strip is placed lengthwise on the cylinder centered on the lines marked on the ends of the cylinder. Load is applied without shock and increased continuously to produce a split tensile stress until the specimen fails and no greater load can be sustained.

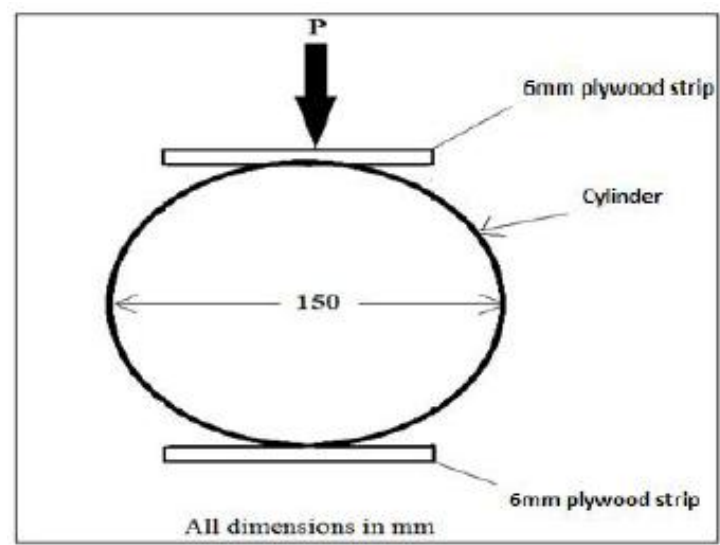

Fig 9 tensile testing

Split tensile strength $=2 P /(\pi d L)$

Where,

$\mathrm{P}=$ Load in $\mathrm{N}$

$\mathrm{d}=$ Diameter of cylinder $=150 \mathrm{~mm}$

$\mathrm{L}=$ Length of cylinder $=300 \mathrm{~mm}$

\section{Flexural strength test}

The standard size of the flexural test specimen is 100x100x500mm.

Here we are applying two point loading on the beam specimen as shown in the fig. 10.

The load was applied till the beam breaks and failure load was noted down.

\section{Flexural strength $=P L / B D^{2}$}

Where,

$\mathrm{P}=$ Load in $\mathrm{N}$

$\mathrm{L}=$ Effective length of beam $=400 \mathrm{~mm}$

$\mathrm{b}=$ Width of the beam $=100 \mathrm{~mm}$

$\mathrm{d}=$ Depth of the beam $=100 \mathrm{~mm}$

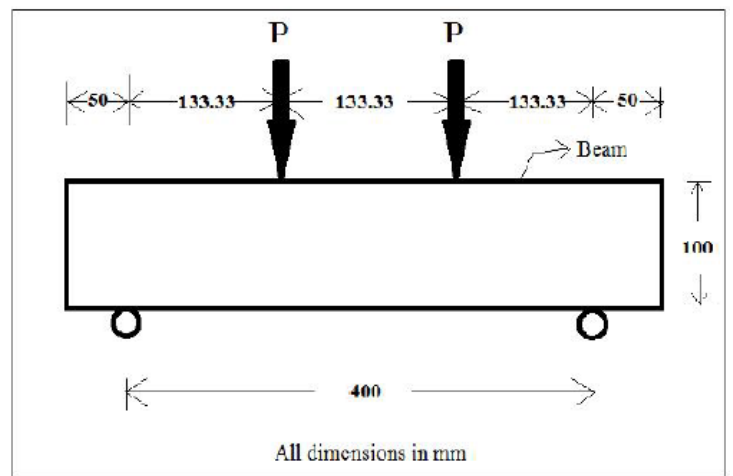

Fig 10 Flexure testing

Published By: 


\section{Shear strength test}

The standard dimensions of the shear strength test specimen is shown in the fig. 11 .

The specimen is placed in the compression testing machine and the load is applied until the cracks are developed and the specimen fails. The cracks and the failure load is notes down.

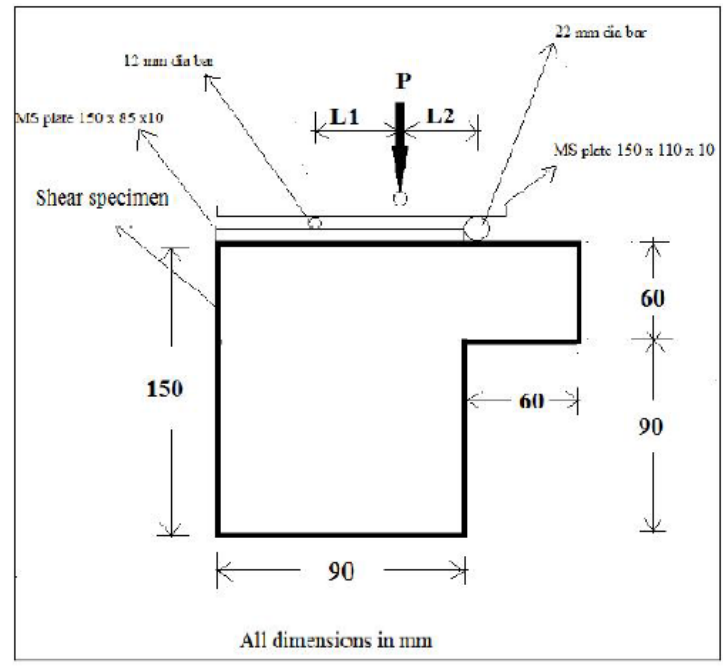

Fig 11 Shear strength testing

\section{Shear strength $=$ Failure load/A}

Where,

Failure load $=$ PL1 $/(\mathrm{L} 1+\mathrm{L} 2)$

$\mathrm{P}=$ Load in $\mathrm{N}$

$\mathrm{A}=$ Area of shear surface $=60 \times 150 \mathrm{~mm} 2, \mathrm{~L} 1=25 \mathrm{~mm}$, $\mathrm{L} 2=25 \mathrm{~mm}$.

\section{Results and Discussions}

The following results were obtained when the tests were conducted on the SIFCON samples

Compression test results.

\begin{tabular}{|c|c|c|c|c|}
\hline Mix & Cement + Mineral admixture & \begin{tabular}{|l} 
Steel + \\
HDPE + WP \\
Fibers
\end{tabular} & \begin{tabular}{|l} 
Compressive \\
strength of \\
reference \\
samples \\
$\left(\mathrm{N} / \mathrm{mm}^{2}\right)$
\end{tabular} & \begin{tabular}{|l|}
\multicolumn{2}{l}{ Compressive } \\
strength of \\
samples after \\
sulfate attack \\
$\left(\mathrm{N} / \mathrm{mm}^{2}\right)$
\end{tabular} \\
\hline Set 1 & $90 \%$ cement $+10 \%$ silica fume & $\begin{array}{ll}1 \% & + \\
0.5 \%+0.5 \%\end{array}$ & 31.5 & 28.5 \\
\hline Set 2 & $90 \%$ cement $+10 \%$ Metakaolin & $\begin{array}{ll}1 \% \\
0.5 \%+0.5 \%\end{array}$ & 31.2 & 28.0 \\
\hline Set 3 & $90 \%$ cement $+10 \%$ GGBS & \begin{tabular}{|l|}
$1 \%$ \\
$0.5 \%+0.5 \%$
\end{tabular} & 32.5 & 29.2 \\
\hline Set 4 & $80 \%$ cement $+20 \%$ silica fume & $\begin{array}{ll}1 \% \\
0.5 \%+0.5 \%\end{array}$ & 28.2 & 27.5 \\
\hline Set 5 & $80 \%$ cement $+20 \%$ Metakaolin & \begin{tabular}{|lr}
$1 \%$ & + \\
$0.5 \%+0.5 \%$
\end{tabular} & 28.6 & 27.6 \\
\hline Set 6 & $80 \%$ cement $+20 \%$ GGBS & $\begin{array}{l}1 \% \\
0.5 \%+0.5 \%\end{array}$ & 28.8 & 27.5 \\
\hline Set 7 & $75 \%$ cement $+25 \%$ silica fume & \begin{tabular}{|lr}
$\%$ & + \\
$0.5 \%+0.5 \%$
\end{tabular} & 27.4 & 26.5 \\
\hline Set 8 & $75 \%$ cement $+25 \%$ Metakaolin & $\begin{array}{l}\% \\
0.5 \%+0.5 \%\end{array}$ & 27.3 & 26.0 \\
\hline Set 9 & $75 \%$ cement $+25 \%$ GGBS & $\begin{array}{l}\% \\
0.5 \%+0.5 \%\end{array}$ & 27.7 & 26.6 \\
\hline Set 10 & $100 \%+0+0$ (Control mix) & $2 \%+0+0$ & 33.5 & 30.5 \\
\hline
\end{tabular}

Published By:

Compressive Strength

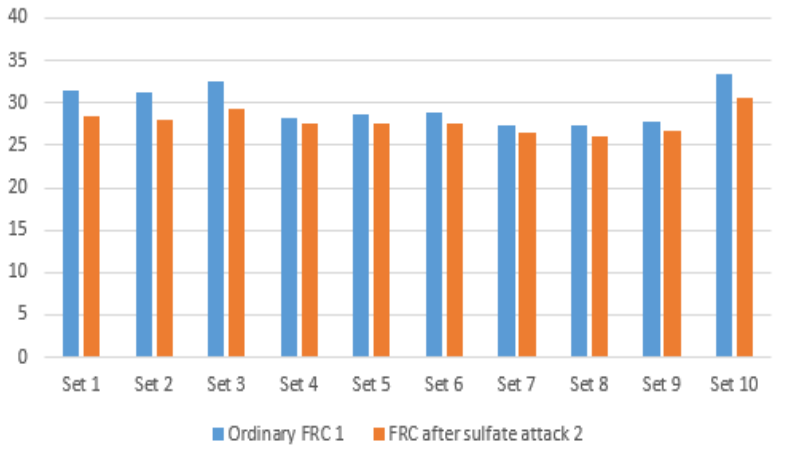

Tensile strength test results

\begin{tabular}{|l|l|l|l|l|}
\hline Mix & Cement + Mineral admixture & $\begin{array}{l}\text { Steel + HDPE + } \\
\text { WP Fibers }\end{array}$ & $\begin{array}{l}\text { Tensile } \\
\text { strength of } \\
\text { reference } \\
\text { samples } \\
\left(\mathrm{N} / \mathrm{mm}^{2}\right)\end{array}$ & $\begin{array}{l}\text { Tensile } \\
\text { strength of } \\
\text { samples } \\
\text { after sulfate } \\
\text { attack } \\
\left(\mathrm{N} / \mathrm{mm}^{2}\right)\end{array}$ \\
\hline Set 1 & $90 \%$ cement + 10\% silica fume & $1 \%+0.5 \%+0.5 \%$ & 6.5 & 6.1 \\
\hline Set 2 & $90 \%$ cement + 10\% Metakaolin & $1 \%+0.5 \%+0.5 \%$ & 6.2 & 5.9 \\
\hline Set 3 & $90 \%$ cement + 10\% GGBS & $1 \%+0.5 \%+0.5 \%$ & 6.6 & 6.2 \\
\hline Set 4 & $80 \%$ cement + 20\% silica fume & $1 \%+0.5 \%+0.5 \%$ & 6.0 & 5.5 \\
\hline Set 5 & $80 \%$ cement + 20\% Metakaolin & $1 \%+0.5 \%+0.5 \%$ & 5.8 & 5.2 \\
\hline Set 6 & $80 \%$ cement + 20\% GGBS & $1 \%+0.5 \%+0.5 \%$ & 6.1 & 5.8 \\
\hline Set 7 & $75 \%$ cement + 25\% silica fume & $1 \%+0.5 \%+0.5 \%$ & 5.4 & 5.1 \\
\hline Set 8 & $75 \%$ cement + 25\% Metakaolin & $1 \%+0.5 \%+0.5 \%$ & 5.3 & 4.8 \\
\hline Set 9 & $75 \%$ cement + 25\% GGBS & $1 \%+0.5 \%+0.5 \%$ & 5.7 & 5.2 \\
\hline Set 10 & $100 \%+0+0$ (Control mix) & $2 \%+0+0$ & 6.8 & 6.3 \\
\hline
\end{tabular}

\section{Tensile Strength}

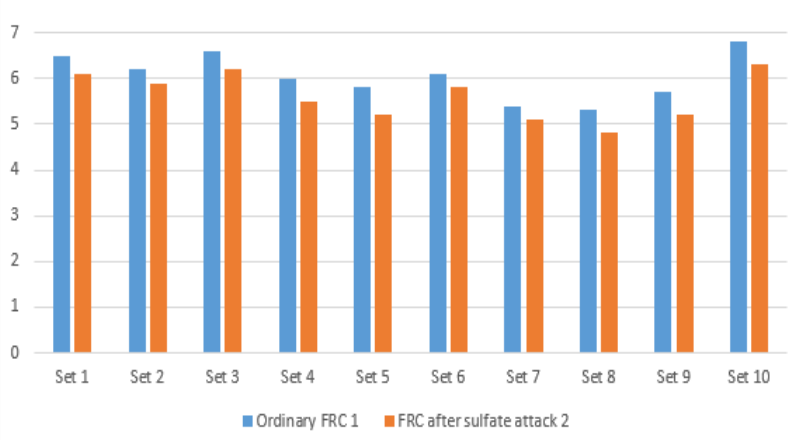

Flexural strength results 


\begin{tabular}{|l|l|l|l|l|}
\hline Mix & Cement + Mineral admixture & $\begin{array}{l}\text { Steel + HDPE + } \\
\text { WP Fibers }\end{array}$ & $\begin{array}{l}\text { Flexural } \\
\text { strength } \\
\text { of } \\
\text { reference } \\
\text { samples } \\
\left(\mathrm{N} / \mathrm{mm}^{2}\right)\end{array}$ & $\begin{array}{l}\text { Flexural } \\
\text { strength } \\
\text { samples } \\
\text { after sulfate } \\
\text { attack } \\
\left(\mathrm{N} / \mathrm{mm}^{2}\right)\end{array}$ \\
\hline Set 1 & $90 \%$ cement + $10 \%$ silica fume & $1 \%+0.5 \%+0.5 \%$ & 14.0 & 12.8 \\
\hline Set 2 & $90 \%$ cement + 10\% Metakaolin & $1 \%+0.5 \%+0.5 \%$ & 14.1 & 13.0 \\
\hline Set 3 & $90 \%$ cement + 10\% GGBS & $1 \%+0.5 \%+0.5 \%$ & 14.2 & 13.3 \\
\hline Set 4 & $80 \%$ cement + 20\% silica fume & $1 \%+0.5 \%+0.5 \%$ & 12.5 & 12.0 \\
\hline Set 5 & $80 \%$ cement + 20\% Metakaolin & $1 \%+0.5 \%+0.5 \%$ & 12.8 & 12.2 \\
\hline Set 6 & $80 \%$ cement + 20\% GGBS & $1 \%+0.5 \%+0.5 \%$ & 13.3 & 12.6 \\
\hline Set 7 & $75 \%$ cement + 25\% silica fume & $1 \%+0.5 \%+0.5 \%$ & 11.8 & 11.3 \\
\hline Set 8 & $75 \%$ cement + 25\% Metakaolin & $1 \%+0.5 \%+0.5 \%$ & 11.3 & 10.6 \\
\hline Set 9 & $75 \%$ cement + 25\% GGBS & $1 \%+0.5 \%+0.5 \%$ & 11.5 & 11.0 \\
\hline Set 10 & $100 \%+0+0$ (Control mix) & $2 \%+0+0$ & 15.4 & 14.8 \\
\hline
\end{tabular}

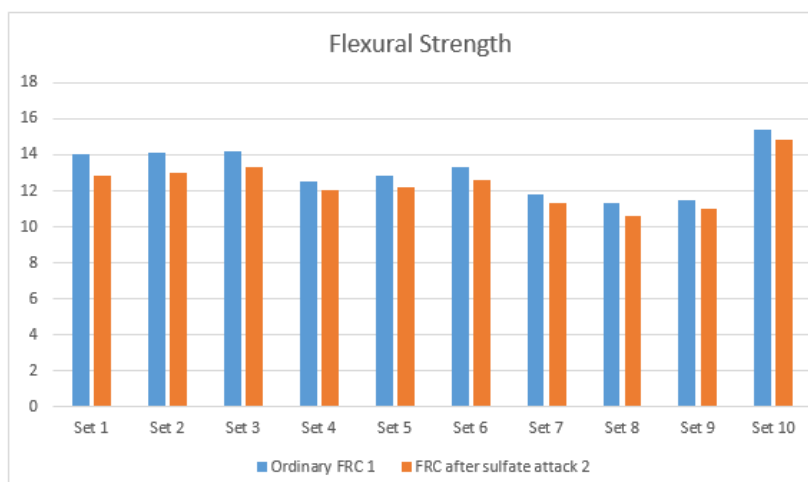

Shear strength results

\begin{tabular}{|c|c|c|c|c|}
\hline Mix & Cement + Mineral admixture & $\begin{array}{l}\text { Steel + HDPE + } \\
\text { WP Fibers }\end{array}$ & $\begin{array}{l}\text { Shear } \\
\text { strength of } \\
\text { reference } \\
\text { samples } \\
\left(\mathrm{N} / \mathrm{mm}^{2}\right)\end{array}$ & $\begin{array}{l}\text { Shear strength } \\
\text { of samples after } \\
\text { sulfate attack } \\
\left(\mathrm{N} / \mathrm{mm}^{2}\right)\end{array}$ \\
\hline Set 1 & $\begin{array}{l}90 \% \text { cement }+10 \% \text { silica } \\
\text { fume }\end{array}$ & $1 \%+0.5 \%+0.5 \%$ & 13.2 & 12.7 \\
\hline Set 2 & $\begin{array}{l}90 \% \text { cement }+10 \% \\
\text { Metakaolin }\end{array}$ & $1 \%+0.5 \%+0.5 \%$ & 13.0 & 12.7 \\
\hline Set 3 & $90 \%$ cement $+10 \%$ GGBS & $1 \%+0.5 \%+0.5 \%$ & 13.4 & 13.0 \\
\hline Set 4 & $\begin{array}{l}80 \% \text { cement }+20 \% \text { silica } \\
\text { fume }\end{array}$ & $1 \%+0.5 \%+0.5 \%$ & 12.0 & 11.7 \\
\hline Set 5 & $\begin{array}{l}80 \% \text { cement }+20 \% \\
\text { Metakaolin }\end{array}$ & $1 \%+0.5 \%+0.5 \%$ & 12.4 & 12.0 \\
\hline Set 6 & $80 \%$ cement $+20 \%$ GGBS & $1 \%+0.5 \%+0.5 \%$ & 12.8 & 12.4 \\
\hline Set 7 & $\begin{array}{l}75 \% \text { cement }+25 \% \text { silica } \\
\text { fume }\end{array}$ & $1 \%+0.5 \%+0.5 \%$ & 11.3 & 11.0 \\
\hline Set 8 & $\begin{array}{l}75 \% \text { cement }+25 \% \\
\text { Metakaolin }\end{array}$ & $1 \%+0.5 \%+0.5 \%$ & 11.1 & 10.8 \\
\hline Set 9 & $75 \%$ cement $+25 \%$ GGBS & $1 \%+0.5 \%+0.5 \%$ & 12.1 & 11.7 \\
\hline Set 10 & $100 \%+0+0$ (Control mix $)$ & $2 \%+0+0$ & 14.2 & 13.8 \\
\hline
\end{tabular}

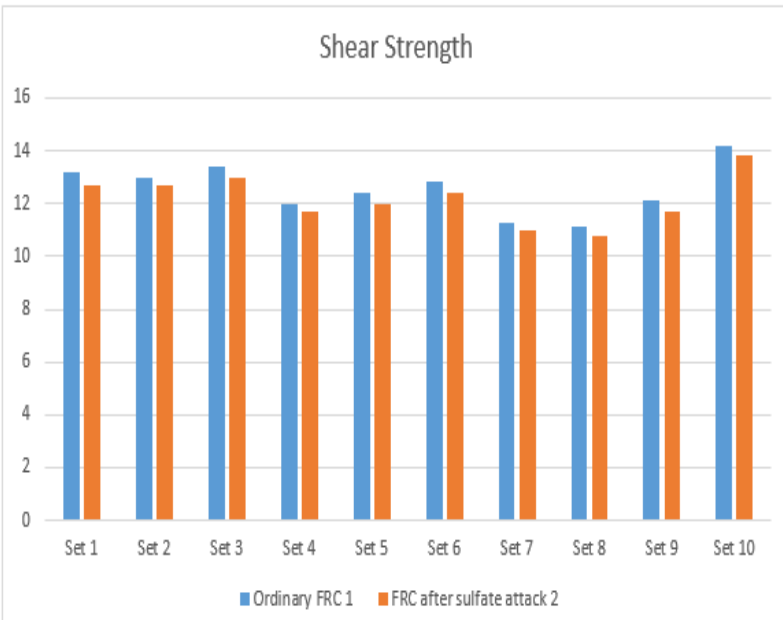

From the above tables we can notice that cement is replaced in 10, 20 and 25 percentages but steel fibers are replaced by $50 \%$ only. Now From the above results it can observed that the control mix (Set 10) has highest strength of all. It is obvious as it has higher cement content and higher steel fiber content. When we replace $10 \%$ of cement by silica fume (set 1), Metakaolin (set 2) and GGBS (set 3) there is a small drop in strength, however GGBS has shown to perform well as the drop in strength is less of all. When we look at the sets 4 to 5 we find that there is further drop in strength as the percentage replacement is 20 . However GGBS is better compared to other two. And when we look at set 7 to 9 there is considerable drop in strength.

So now when we compare these test results with that of the samples which were immersed in magnesium sulfate solution we find there is a considerable difference $n$ strength. It is seen that sulfate has considerably affected the strength of the concrete over a period of 90days. However as the concentration of sulfate in that solution was 5 which is too high and the soil and sea water do not have these concentrations so it can be expected that these mixes will perform better in the actual environment where the sulfate concentration is lower than the test solution. Overall results show that replacing cement in FRC by up to $20 \%$ does reduce strength but however it is still close to the design strength. That too GGBS has performed well as does not reduce the strength much and its performance is good in sulfate solution as well.

\section{CONCLUSIONS:}

From the experiments conducted it can be observed that the strength of the FRC reduces as the percentage replacement of cement by mineral admixture is higher. But when the percentage replacement of cement was just $10 \%$ the strength obtained will be almost nearer to that of the control mix. However 10\% replacement of cement by mineral admixtures does not seem to be much cost effective. So if we consider a higher percentage replacement of cement, it can be observed that strength of the FRC with $20 \%$ replacement of cement is almost nearer to that of the FRC produced with $10 \%$ replacement of cement by Mineral

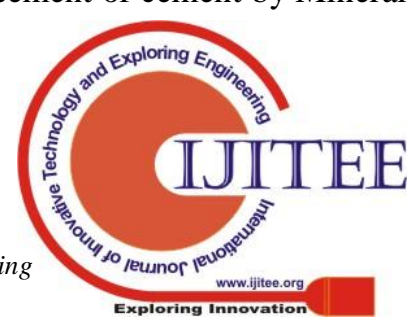


admixtures, where as if we observe the performance of FRC produced with replacement of $25 \%$ of cement by mineral admixtures is considerably low.

So we can say that the optimum percentage of replacement of cement by any mineral admixture should be 20.

When we observe the performance of each mineral admixtures we can see that the ground granulated blast furnace flag is comparatively better.

It can also be seen that $50 \%$ replacement of steel fibers with waste plastic fibers does not reduce the strength of the FRC significantly.

So after observing the experimental results it can be concluded that we can effectively reduce the cost of production of FRC by replacing $20 \%$ of cement by GGBS and by replacing $50 \%$ of steel fibers by waste plastic fiber without reducing the performance considerably.

\section{REFERENCES}

1. Vikrant S. Vairagade, Kavita S. Kene, "Experimental investigation on hybrid fiber reinforced concrete", International Journal of Engineering Research and Applications, Vol. 2, Issue 3, May-Jun 2014, pp.1037-1041.

2. Vinayak vijapur, satish jyanopanthar, "Behaviour of steel fiber reinforced polymer concrete with partial replacement of cement by Metakaolin" International Journal of Engineering Research and Applications, Vol. 2, Issue 4, Aug 2014, pp.202-211.

3. Yatheesh kumar S, Dr. K.B Prakash, "Performance evaluation of ternary blended hybrid fiber reinforced concrete", Vol. 2, Issue 4, July 2014, pp.18-30

4. Nikhil A. Gadge , S. S. Vidhale, "Mix Design of Fiber Reinforced Concrete (FRC) Using Slag \& Steel Fiber", International Journal of Modern Engineering Research, Vol. 3, Issue. 6, Nov - Dec. 2013 pp-3863-3871.

5. E. Arunakanthi, J. D. Chaitanya Kumar, "Experimental studies on fiber reinforced concrete", International Journal of Civil Engineering and Technology (IJCIET) Volume 7, Issue 5, September-October 2016, pp. 329-336.

6. Sadat Ali Khan, Dr. K. B. Prakash, Behaviour of SIFCON produced with hybrid fibres under sulfate attack, International journal of Engineering Research-Online, Vol.2., Issue.4, Aug2014, 154-164.

7. A.M. Shende, A.M. Pande, M. Gulfam Pathan, "Experimental Study on Steel Fiber Reinforced Concrete for M-40 Grade", International Refereed Journal of Engineering and Science (IRJES) ISSN (Online) 2319-183X, (Print) 23191821 Volume 1, Issue 1 (September 2012), PP. 043-048.

8. Abdul Ghaffar, et al, "Steel Fibre Reinforced Concrete", International Journal of Engineering Trends and Technology (IJETT) - Volume 9 Number 15 - Mar 2014

9. Kailash bheemraj kumawat, et al, "Effects of replacement of Metakaolin with cement on the mechanical properties of SIFCON", International journal of research in Engineering and technology, Vol.5, issue : 01, Jan 2016

10. Lankard.D.R "Properties and applications of slurry infiltrated fibre concrete" Concrete international, Dec-1984,pp 44-4 